\title{
Diapause and quiescence in eggs of Systellognatha stonefly species (Plecoptera) occuring in alpine areas of Norway
}

\author{
A. Lillehammer ${ }^{1}$
}

Keywords : Plecoptera, egg diapause, quiescence period, temperature dependence.

Eggs of the stoneflies Diura bicaudata and Arcynopteryx compacta, occurring in the middle-alpine vegetation belt, and Dinocras cephalotes not recorded above the sub-alpine, reacted differently to the same temperatures. Those of $D$. bicaudata and A. compacta had a diapause during the winter. D. cephalotes eggs went into a stage of quiescence when the water temperature was lowered from $16^{\circ} \mathrm{C}$ to $8^{\circ} \mathrm{C}$ or below. They remained alive in this stage for about a year, but this quiescence could be broken at anáy time when the eggs were transferred to 16 and $20^{\circ} \mathrm{C}$.

Freezing at $-6^{\circ} \mathrm{C}$ followed by an increase in the water temperature led to a break in the diapause of $A$. compacta eggs after five months, but not of $D$. bicaudata eggs.

Eggs of $D$. bicaldata began to hatch after nine months independently of previous freezing followed by an increase in water temperature. Eggs of D. bicaudata held at a constant temperature of $1.5^{\circ} \mathrm{C}$ also began to hatch at the same time as those kept at $8^{\circ}$ or $16^{\circ} \mathrm{C}$. However, the point of $50 \%$ hatching was much delayed at $1.5^{\circ} \mathrm{C}$.

The egg diapause of A. compacta and D. bicaudata is an adaptation to areas with a severe climate typified by long cold winters and short summers. The quiescence period of $D$. cephalotes eggs enables the species to survive outside its normal distribution area.

Diapause et quiescence des cufs de Plécoptères (Systellognatha) des zones alpines de Norvège.

Mots clés: Plecoptera, diapause des œufs, quiescence, température.

Les $\propto u f s$ des Plécoptères Diura bicaudata, Arcynopteryx compacta et Dinocras cephalotes réagissent différemment aux mèmes températures. Ceux de $D$. bicaudata et $A$. compacta ont une diapause hivernale. Les œufs de $D$. cephalotes sont entrés en quiescence lorsque la température était abaissée de $16^{\circ} \mathrm{C}$ à $8^{\circ} \mathrm{C}$ ou au-dessous.

Dans ces conditions, ils sont restés vivants environ une année mais leur quiescence pouvait être stoppée à tout instant par un relèvement de la température à $16^{\circ}$ et $20^{\circ} \mathrm{C}$.

Un refroidissement à $-6^{\circ} \mathrm{C}$ suivi par une augmentation de température de l'eau a entrainé une levée de la diapause chez $A$. compacta après cinq mois, mais pas chez $D$. bicaudata.

Les ceufs de $D$. bicaudata ont commencé à éclore après neuf mois, même s'ils étaient, comme dans le cas précédent, refroidis puis rechauffés. Les œufs de $D$. bicaudata, maintenus à une température constante de $1,5^{\circ} \mathrm{C}$ commencèrent aussi à éclore en même temps que ceux conservés à $8^{\circ}$ ou $16^{\circ} \mathrm{C}$. Cependant, le temps nécessaire à l'éclosion de $50 \%$ des œufs était plus long à $1,5^{\circ} \mathrm{C}$.

La diapause des cufs de $A$. compacta et $D$. bicaudata est une adaptation aux régions à climat rude caractérisé par un hiver long et froid et un été court. La période de quiescence des cufs de $D$. cephalotes permet à l'espèce de survivre en dehors de sa zone nonnale de distribution. 


\section{Introduction}

The eggs of a number of stonefly species, mainly Systellognatha, are known to have a diapause during the winter, (Khoo 1968, Lillehammer 1976, Saltveit \& Lillehammer 1984). The eggs of other species have no obligatory diapause, but hatch after a shorter or longer period, depending upon the ambient water temperature, (Lillehammer 1976, 1986, Saltveit \& Lillehammer 1984).

The factors which lead to the onset of a diapause are not yet fully understood, although Sweeney (1984) states that water temperature influences the pre-diapause, the length of the diapause and the duration of the post-diapausal development. Dowes (1965) states that, as an adaptation to the arctic environment, the initiation and control of the seasonal development cycle depends primarily on water temperature, the changes in photoperiods being ineffective under arctic conditions.

Those factors responsible for breaking the diapause, such as temperature, are investigated and discussed in the present paper. Experiments have been made to investigate the role of cooling and even freezing the eggs. For this purpose the eggs of two species of stonefly, Arcynopteryx compacta and Diura bicaudata, were studied. In Fennoscandia, the eggs of both species have an obligatory diapause during the winter (Lillehammer 1976).

In addition, eggs of Dinocres cephalotes, which do not develop at temperatures much below $12^{\circ} \mathrm{C}$ ( $\mathrm{Li}$. lehammer 1987), were studied to find out whether a temperature-regulated period of quiescence occurs in this species.

\section{Materials and Methods}

The experiment included $\mathbf{4 0 0}$ eggs of Arcynopteryx compacta, 800 eggs of Diura bicaudata and 780 eggs of Dinocras cephalotes. Mature males and females of the three species were caught in the field and kept in the laboratory until eggs had been deposited. $\boldsymbol{A}$. compacta and $D$. bicaudata were both taken from the same biotope, an outlet stream at Valdresflya in the Jotunheimen mountains of central Norway at about $1400 \mathrm{~m}$ a.s.l. D. cephalotes was caught in a river in $\phi y s t r e$ Slidre, about $50 \mathrm{~km}$ south of Valdresflya and about $300 \mathrm{~m}$ a.s.l.
Eggs of $A$. compacta and D. bicaudata were placed in water at $12^{\circ} \mathrm{C}$ in a temperature cabinet for a period of 60 days, while they developed and entered into the diapause.

The development of the eggs of $D$. cephalotes was started at $16^{\circ}$ and then stopped, by placing them in water at $8^{\circ} \mathrm{C}$. Some eggs of this species were also first kept at a temperature of $4^{\circ} \mathrm{C}$ and then transferred to $20^{\circ} \mathrm{C}$ for further development.

Egg volumes were calculated from the formula $V=a b^{2} \pi / 6$, where $a$ is the egg length and $b$ the egg width. The measurement of both eggs and nymphs were made under a stereomicroscope, to an accuracy of $\pm 0.01 \mathrm{~mm}$. The mean egg volumes of $A$. compacta and $D$. bicaudata were respectively $613 \times 10^{5} \mu \mathrm{m}^{3}$ and $339 \times 10^{5} \mu \mathrm{m}^{3}$, the respective ranges being $418 \times 10^{5} .723 \times 10^{5} \mu \mathrm{m}^{3}$ and $298 \times 10^{5} .339 \times 10^{5} \mu \mathrm{m}^{3}$. The mean egg volume of D. cephalotes was $433 \times 10^{5} \mu \mathrm{m}^{3}$, the range $431 \times 10^{5}-439 \times 10^{5} \mu \mathrm{m}^{3}$. The body length of newborn nymphs of $A$. compacta varied from 1.28 to $1.67 \mathrm{~mm}$, and those of D. bicaudata from 1.16 to $1.52 \mathrm{~mm}$.

\section{Results}

\subsection{Dinocras cephalotes}

After being kept for 20 days in water at $16^{\circ} \mathrm{C}$, the eggs were then transferred to water at $8^{\circ} \mathrm{C}$ (Table 1). Development stopped and the eggs went into a temperature dependent state of quiescence. After periods of 56, 221 and 324 days respectively, three batches of eggs were taken out and placed in water at $20^{\circ} \mathrm{C}$. All three groups required about the same number of days to complete the incubation period. irrespective of the length of time they had been kept at $8^{\circ} \mathrm{C}$.

In addition one batch of eggs was kept at $4^{\circ} \mathrm{C}$, one at $1^{\circ} \mathrm{C}$, and one was even frozen into a block of ice at $-6^{\circ} \mathrm{C}$ for seven days. After being transferred to water at $20^{\circ} \mathrm{C}$ they required 31,32 and 30 days, respectively, before they hatched, a result similar to that recorded for those kept initially at $8^{\circ} \mathrm{C}$. They were not influenced by the low temperature and freezing. Altogether 290 eggs placed at $4^{\circ} \mathrm{C}$ for 20 days just after deposition did not develop at all when subsequently kept at water temperatures of $16^{\circ}, 20^{\circ}$ and $24^{\circ} \mathrm{C}$ for 150 days. A temperature of $4^{\circ} \mathrm{C}$ seems to be lethal to eggs at that early stage of development. 
Table 1 : Degree of hatching success of eggs of Dinocras cephalotes when kept at different water temperatures for different periods of time, $(N)$ number of eggs.

\begin{tabular}{|c|c|c|c|c|c|c|c|c|}
\hline & \multirow[b]{2}{*}{$\mathbf{N}$} & \multicolumn{6}{|c|}{$\begin{array}{l}\text { No. of days keot at the } \\
\text { different temperatures }\left({ }^{\circ} \mathrm{C}\right)\end{array}$} & \multirow{2}{*}{$\begin{array}{l}\text { Hatching } \\
\text { swccess }\end{array}$} \\
\hline & & $8^{0}$ & $b^{0}$ & $1^{0}$ & $-6^{0}$ & $16^{0}$ & $20^{0}$ & \\
\hline 1 & 128 & & & & & & 33 & 100 \\
\hline 2 & 250 & 76 & & & & & & 0 \\
\hline 3 & 120 & 107 & & & & & & 0 \\
\hline 4 & 85 & 153 & & & & & & 0 \\
\hline 5 & 91 & 56 & & & & & 31 & 96 \\
\hline 6 & 15 & 221 & & & & & 32 & 66 \\
\hline 7 & 140 & 326 & & & & & 35 & 93.4 \\
\hline 8 & 36 & 49 & 7 & & & & 31 & 95 \\
\hline 9 & 55 & 114 & & 16 & & & 32 & 100 \\
\hline 10 & 28 & 151 & & & 7 & & 30 & 100 \\
\hline 1 & 26 & 300 & & & & 10 & $2 \mathrm{a}$ & 50 \\
\hline
\end{tabular}

\subsection{Diura bicaudat a}

Ten batches of eggs were placed in a temperature cabinet at $12^{\circ} \mathrm{C}$ shortly after deposition on $21 \mathrm{June}$ 1984. On 26 August head capsules with eye pigmentation were recognizable. Some other body structures were also visible. The heads all pointed downwards. At this stage they entered into a diapause. On 13 November all the eggs were placed in water at $1.6^{\circ} \mathrm{C}$, and the temperature reduced to $0.5^{\circ} \mathrm{C}$ by 12 December. On 27 December, in an attempt to break the diapause, some batches of eggs were frozen at $-6^{\circ} \mathrm{C}$ for seven days, and thereafter placed in water at $8^{\circ} \mathrm{C}$ (Table 2). No hatching occurred within three months, although 10 eggs reached the terminae stage, i.e. the stage just prior to hatching, shortly after the freezing. A repetition of this experiment, made between 18-25 January yielded the same result, although a greater percentage of the eggs terminated this time ( 30 out of 45 ). None of these eggs hatched, even when kept to 20 June.

A third experiment, in which the eggs were only transferred from $0.5^{\circ} \mathrm{C}$ to water at $8^{\circ} \mathrm{C}$ on 8 January, without being frozen, gave the same results as the two previous ones.

However, in a fourth experiment after freezing on 14 March for one month, and then being exposed to full daylight for 8 hours, all the eggs hatched successfully during the latter half of April when transferred to water at $8^{\circ} \mathrm{C}$. The same result was also recorded when eggs on 29 April were transferred from $1.5^{\circ} \mathrm{C}$ to water of $8^{\circ}$ and to $16^{\circ} \mathrm{C}$ at 2 May without having been exposed to daylight. Those eggs which had been kept at a constant water temperature of $1.5^{\circ} \mathrm{C}$ from 20 February also began to hatch at the same time. The only difference noted was in the duration of the hatching period. At $16^{\circ} \mathrm{C}$ the hatching was completed in 6.13 days, while at $1.5^{\circ} \mathrm{C}$ hatching took $34-73$ days.

On 12 June, one batch of eggs was transferred from $1.5^{\circ} \mathrm{C}$ to $8^{\circ} \mathrm{C}$, and then to $16^{\circ} \mathrm{C}$ on the 15 th. By 20 June, 200 nymphs had hatched successfully.

\subsection{Arcynopteryx compacta}

The eggs were placed in a temperature cabinet at $12^{\circ} \mathrm{C}$ shortly after deposition on 12 July 1984 . They entered into the diapause at a much earlier stage than the eggs of $D$. bicaudata, but head capsules were not clearly visible. The same experiments were made with the eggs of this species as already described for $D$. bicaudata. The results obtained were different.

After freezing at $-6^{\circ} \mathrm{C}$ from 27 December 1984 to 3 January 1985, the eggs then developed very fast when placed at $8^{\circ} \mathrm{C}$ and the nymphs hatched after 18 days (Table 3). Freezing on 18 January yielded a similar result, complete hatching success after an incubation period of 19 days at $8^{\circ} \mathrm{C}$. The eggs were observed to shrink in size during freezing.

A control experiment made on 8 January 1985 in which eggs were transferred from $0.5^{\circ} \mathrm{C}$ to $8^{\circ} \mathrm{C}$ without freezing, resulted in no hatching taking place after three months.

Freezing for one month from 14 March to 17 April also resulted in full hatching success after 12 days at $16^{\circ} \mathrm{C}$.

In a control experiment made from 20 February to 29 April eggs were transferred from $1.5^{\circ} \mathrm{C}$ to $8^{\circ} \mathrm{C}$ and then to $16^{\circ} \mathrm{C}$ on 2 May. After one day at full daylight, the majority of eggs failed to hatch, only two did so.

In June, one batch of egg was transferred to $8^{\circ} \mathrm{C}$ on the 12 th and to $16^{\circ} \mathrm{C}$ on the 15 th. 123 nymphs had hatched by the 24 th. 
Table 2 : Eggs of Diura bicaudata deposited on 12-15 July 1984 and placed in water of $12^{\circ} \mathrm{C}$ on the same day, transferred to a water temperature of $1^{\circ} \mathrm{C}$ on 13 November 1984 and of $0.5^{\circ}$ on 12 December 1984. (N) nurnber of eggs.

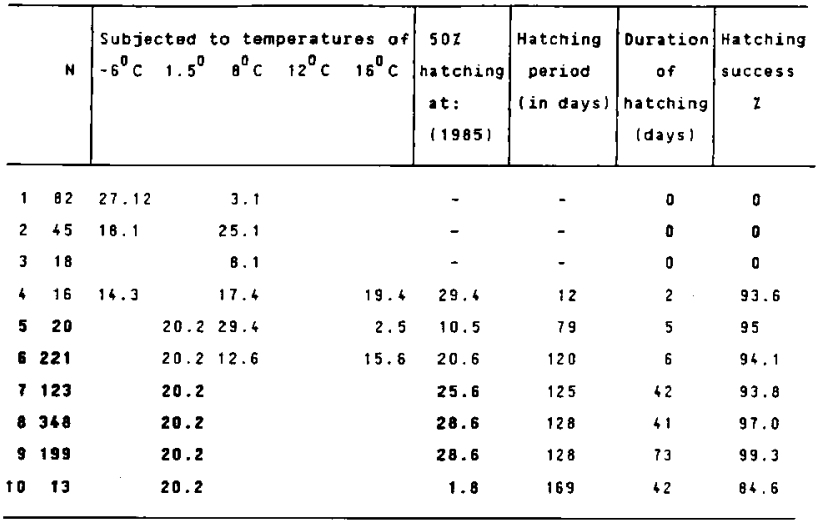

Table 3 : Eggs of Arcynopteryx compacta deposited on 10-12 July 1984 and placed in water of $12^{\circ} \mathrm{C}$ on the same day. They were transferred to a water temperature of $1^{\circ} \mathrm{C}$ on 13 November 1984 and then to $0.5^{\circ} \mathrm{C}$ on 12 December 1984. (N) number of eggs.

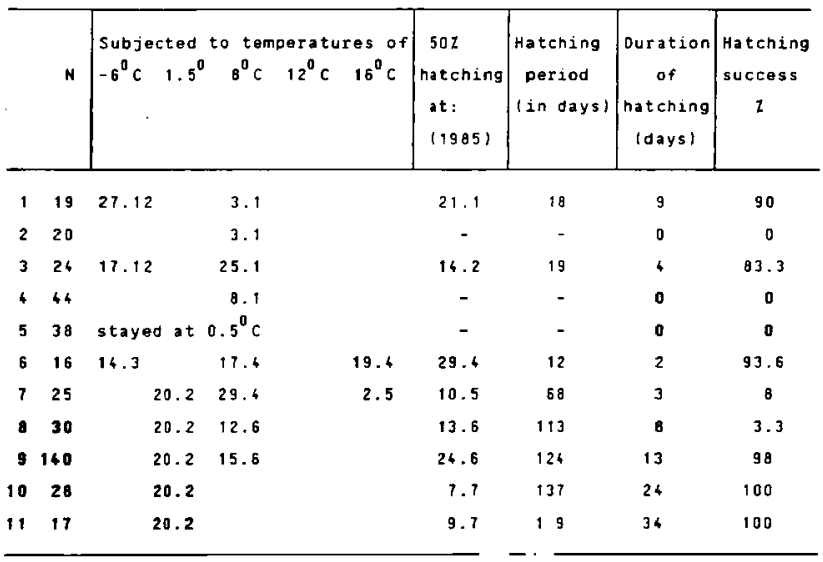


At a constant temperature of $1.5^{\circ} \mathrm{C}$ two egg batches began to develop during early May and the nymphs were recognizable. By 20 May. They began to hatch in late June, over a period of 24-34 days, but the overall hatching success was low. 38 eggs kept at $0.5 \mathrm{C}$ all the time, they did not hatch, even in June.

\section{Discussion}

Eggs of Diura bicaudata and Arcynopteryx compacta entered into a diapause at a water temperature of $12^{\circ} \mathrm{C}$. Development of the Dinocras cephalotes eggs was only stopped by placing them in water of $8^{\circ} \mathrm{C}$ after being kept at $16^{\circ} \mathrm{C}$. The differences between them are: While the eggs of the first two species have an obligatory diapause, the eggs of Dirocras cephalotes have a temperature dependent period of quiescence at a water temperature of $8^{\circ} \mathrm{C}$ or below. The water temperature could be lowered to $1.0^{\circ} \mathrm{C}$, and the eggs even frozen into a solid block of ice at $-6^{\circ} \mathrm{C}$ for six days without any harm. At $8^{\circ} \mathrm{C}$ they were successfully kept alive from July one year to June the following year. This means that at localities where suitable egg development temperatures occur for only a shorter period, the eggs of this species are able to remain quiescent for a whole year if necessary. This ability would appear to be very important for the species to be able to maintain local populations outside its optimal area of distribution, such as in high altitudes, and north of the polar circle (Lillehammer 1985 a).

The two species with eggs requiring an obligatory diapause react differently to changes in water temperature, While the eggs of D. bicaudata seem to be little influenced by a lowering of water temperature, and even by freezing, early in winter, the diapause lasts for 8-10 months independent of changes in temperature including freezing. The eggs of $A$. compacta however, could be taken out of the diapause relatively early (December and January) by freezing the eggs for a period. Such freezing seems to induce a more rapid development when the eggs are afterwards placed in water of higher temperatures.

However, eggs of $A$. compacta held at a constant temperature of $1.5 \mathrm{C}$ began to develop during the first half of May and then required about the same time for full development as those of D. bicaudata. In May and June the eggs of both species hatched when kept at constant temperatures, even at $1.5^{\circ} \mathrm{C}$.
An increase in the water temperature during the postdiapausal period of eggs of Diura bicaudata seems greatly to shorten the time required for full development. These two species mainly occure in different types of habitats. In southern Fennoscandia $D$. bicaudata occurs in lakes with water temperatures between $0^{\circ} \mathrm{C}$ and $4^{\circ} \mathrm{C}$ during the winter. whereas A. compacta occurs in streams that are frozen during the greater part of the winter. Eggs of the latter species therefore seem to be more dependent on water temperature for full hatching success, while eggs of D. bicaudata go through a time dependent development phase which may last for a longer period.

The type of egg development of each of the three species of stonefly has individually adapted to the particular enviromental factors of its habitat. The eggs of $D$. cephalotes can enter into a state of egg quiescence for up to a year. Although it is a warm stenotherm species, which originated in the Mediterranean (Zwick 1981), it is also able to live at high altitudes such as in Ovre Heimdalen, in central Norway (Lillehammer \& Brittain 1978) and at high latitudes, in northern Fennoscandia - habitats in which two summers are required for egg hatching in some years. The eggs of the other two species, which are the two most abundant species found in the alpine areas of Fennoscandia, seem to be well adapted to their habitat by entering into a diapausal state throughout their first winter, at low water temperatures and then utilising the entire warm period of about three months for nymphal growth. This fits with Khoo's (1968) suggestion that a diapause is an adaptation to a very cold climate and that the occurrence of non-diapausal eggs of Diura bicaudata in Lake Bala in England is a recently evolved feature. It is thought that over a greater part of Norway both $D$. bicaudata and A compacta occur within the areas of optimal water temperature for these two species. This fits also with the concept of geographical thermal equilibrium, proposed by $V$ annot \& Sweeney (1980), who state that for successful reproduction aquatic insects should live within the regions of their optimal temperature. However, $D$. cephalotes does occur outside its thermal optimum area, at high altitudes and in northern Fennoscandia. Its eggs therefore need to be specially temperature adapted to such habitats by tolerating a long period of quiescence necessary to adapt to the 
annual temperature regime so that the nymphs wil hatch at a suitable time for subsequent mating and reproduction of adults.

For two of the species Dinocras cephalotes and Arcynopteryx compacta the changes in water temperature seem to be the most important factor for regulating egg development. Dowes (1965) statement, that the control of the seasonal development cycle under arctic condition depends primarily on the water temperature, seems to well apply to those species studied here. Both Arcynopteryx compacta and Diura bicaudata live in the middle alpine zone, which climatically closely parallels arctic conditions.

Plasticity in life cycle occurs in all three species studied. Dinocras cephalotes is able to go into an egg quiescence when the water temperature is low, as in high altitudes during most of the year. The egg development can then be prolonged from three months to one year. The quiescence of the eggs of D. cephalotes occurs also in the Pyrenean populations (Berthélemy in litt., unpublished results). Diura bicaudata can either have only diapausing eggs, as in this study, or have both diapausing and nondiapausing eggs (Khoo 1968). A. compacta which occur in the Pyrenees (Berthelemy 1966), can have an prolonged nymphal growth period producing a three year life cycle (Lavandier 1979) or in the case of Mountain lake outlet biotopes a two year life cycle (Lillehammer 1985 b).

\section{Acknowledgements}

I am gratefull to Phillip Tallantire for correcting the language, to Prof. Lauritz Somme for comments on the manuscript, and to Karsen Sund for technical assistance.
References

Berthèlemy (C.). 1966. - Recherches ecologiques et biogégraphiques sur les Plécoptères et Coléoptères d'eau (Hydraena et Elminthidae) des Pyrénées. Annls Limnol., 2: 227458.

Downes (J.A.). 1965. - Adaptations of insects in the arctic. A. Rev. Ent., $10: 257+274$.

Khoo (S.G.) 1968. - Experimental studies on diapause in stoneflies. II. Eggs of Diura bicaudata (L.). Proc. $R$. ent. Soc. Lond. A., $43: 40-48$

Lavandier (P.). 1979. - Cycle biologique, régime alimentaire, production d'Arcynopteryx compacta (Plecoptera, Perlidae) dans un torrent de haute altitude. Bull. Soc. Hist. nat. Toulouse, 115 . (1-2): 1-11.

Lillehammer (A.). 1976. - Norwegian stoneflies V. Variations in morphological characters compared to differences in ecological factors. Norw. J. Ent., 23:161-172.

Lillehammer (A.). 1985 a. - Zoogeographical studies on Fennoscandian stoneflies (Plecoptera). J. Biogeogr., $12: 209-221$.

Li]lehammer (A.) 1985 b. - The coexistence of stoneflies in a moun. tain lake outlet biotope. Aquatic ins., $7: 173-187$.

Lillehammer (A.). 1987. - Egg development of the stoneflies Sipho noperla burmetsteri (Chloroperlidae) and Dinocras cephalotes (Perlidae). J. freshu: Biol, 17 : 35-39.

Lillehammer (A.) \& Brittain (J.E.). 1978. - The invertebrate fauna of the streams in ovre Heimdalen. Holarct. Ecol. $1: 271-276$.

Saltveit (S_J.) \& Lillehammer (A.). 1984. - Studies on egg development in the Fennoscandian Isoperla species. Annls Limnol., 20 $(1-2): 91-94$

Sweeney (B.W.). 1984. - Factors influencing life history patterns of aquatic insects. In V.H. Resh \& D.M. Rosenberg: The ECOlogy of Aquatic Insects. Praeger, New York. $625 \mathrm{pp}$.

Vannot (R.L.) \& Sweeney (B.W.). 1980. - Geographic analysis of thermal equilibria: A conceptual model for evaluating the effect of natural and modified thermal regimes on aquatic insect communities. Amer. Nat., 115:667-695.

Zwick (P.). 1981. - Das Mittelgebiet als glaziales Refugium für Plecoptera. Act. ent. Jugosl., $17: 107-111$. 